\title{
Numerical Taxonomy of Local Streptomyces isolates
}

$$
\text { التصنيف العددي لعزلات محلية من بكتريا ستربتومايسس }
$$

Rebah N. Al-Gafadri

Rehab S. Al-Qaragoli*

Asia J. Al-Rubaie

W. Abdul-Mallik *

Biotechnology Research Center/ Al- Nahrain University

* College of Science/ Biotechnology Department/Al- Nahrain University

\section{Abstract}

In this study, 11 local Streptomyces isolates were studied for 55 criteria that they possessed which included morphological, and biochemical one. Using clustering algorithm we found that these isolates are lying in $\mathbf{3}$ major clusters and they construct 10 minor clusters according to their genetic distance. We were able to conclude that these isolates were driven from two common ancestors that possessed the longest genetic distance between them. Using proposal published by Williams et al, 1981, we were able to classify these isolates into 4 major species groups which are $S$. rochei, $S$. diataticus, S. chromofucud, and S. atroolivaceus. Only two of the 11 isolates were not classified to a major species group since they did not match the criteria given by Williams et al., 1981 that required further investigation.

تم في هذه الدراسـة التحري عن 55 صفة لـ 11 عزلة بكتيريـة من جنس ستربتومايسس والتي تضمنت الصفات المظهرية والبيوكيمياوية بأستخدام خوارزمية التجميع العنقودي ، وجدنا ان هذه العزلات تقع في ثُلاث مجموعات

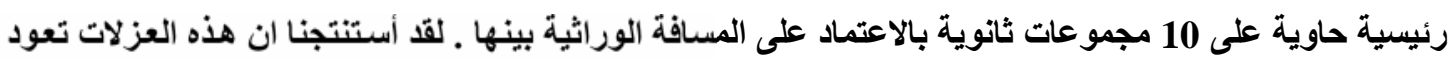

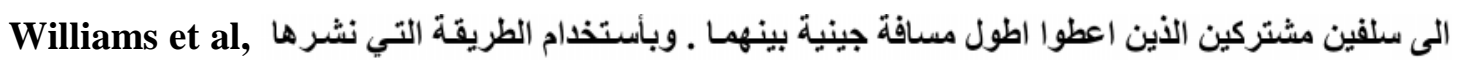
1981 اسنطعنا تصنيف هذه العزلات الى الانواع الرئيسية لها والتي تثنمل S. rochei, S. diataticus, S1

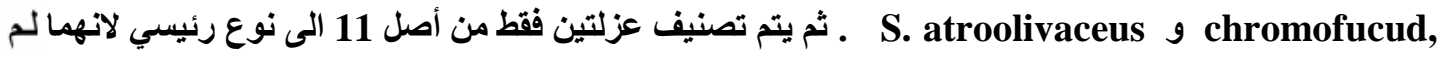
يطابقا المواصفات التي اعطاها الباحث اعلاه مما يستدعي معقة اكثر . 


\section{Introduction}

The genus Streptomyces was proposed by Waksman \& Henrici (1943) for aerobic, spore- forming actinomycetes, which had been previously termed actinomycetes. The genus currently accommodates aerobic Gram-positive actinomycetes that are highly oxidative, form extensive branching substrate and aerial mycelia containing LL-diaminopimelic acid (LDAP) and glycine but no characteristic sugar in the wall (wall chemotype I sensu), and have a DNA base composition within the range 69 to 73 mol \% guanine $(\mathrm{G})$ plus cytosine $(\mathrm{C})$ (Pridham \& Tresner, 1974).

Fragmentation of the substrate mycelium is infrequent and spores are rarely produced on the substrate hyphae (Shirling \& Gotllieb, 1968). The aerial hyphae usually bear long chains of spores (>50 spores), but in certain species shorter spore chains occur (Becker et al., 1965). Streptomyces and related genera with a wall chemotype I have been shown to form a phylogenetically distinct taxon in 16s rRNA oligonucleotide sequencing and DNA-rRNA studies (Stackebrandt \& Woese, 1981).

Streptomycetes are well-known as a rich source of antibiotics and proof of the novelty of an antibiotic has frequently rested on the description of the producer as a new species. This practice, coupled with the failure of taxonomists to find reliable tests for the identification of streptomycetes, has resulted in the proliferation of 'species', many of which were proposed on trivial differences in morphological and cultural properties (Waksman, 1957). Between 1940 and 1957 over 1000 Streptomyces species were described (Pridham et at., 1958). A number which had swollen to about 3000 by 1970, although many of these additional taxa had merely been cited in the patent literature (Trejo, 1970).

Numerous classifications were devised to accommodate the increasing number of Streptomyces species. Most of them based on a few subjectively chosen morphological and pigmentation properties, which were rarely studied under standardized growth conditions. Gause et al. (1957) recognized 15 groups or series distinguished by aerial and substrate mycelia color, Pridham et al. (1958), 42 groups defined by sporophore morphology and aerial mycelium color, Shinobu (1958), 13 groups based on sporophore morphology, melanin and nitrite production, while Waksman (1961) classified over 250 species into 16 series using aerial and substrate mycelium color, spore chain morphology, melanin 
production and a number of other properties including proteolysis. Some taxonomists equated series with species. Pridham et al. (1965) reduced 400 Streptomyces species on the basis of spore ornamentation and spore chain morphology. Pridham (1976) recognized 10 species on the same grounds, whereas Hutter (1967) described 41 species using four criteria, sporophore morphology, aerial and substrate mycelium color and melanin production. Biochemical, nutritional and physiological characters have also been frequently used in streptomycete systematics, but have usually been applied to only selected species (Okami, 1952; Benedict et al., 1955; Waksman, 1957; Shinobu, 1958; Tresner \& Danga, 1958).

By the early 1950s, it was becoming increasingly clear that streptomycete taxonomy had serious problems. In 1964,

\section{Materials and Methods}

Media: The following media were employed during the experiments

R2 Medium, R2 YE medium, Yeast extract - malt extract (YEME) Complete medium for streptomycetes, Melanin production medium (Hopwood et al., 1985), Trypticase soya broth (TSB) ( Oxoid), Gauza agar (Komagata, 1986), S medium (Okanishi et al., 1974), a collaborative study, the International Streptomyces Project (ISP) was established to furnish reliable description of authentic, extant type strains of Streptomyces and related taxa using a small number of traditional tests applied under standard conditions (Shirling \& Gottlieb, 1966; Gottlieb \& Shirling, 1967). Over 450 species were re described, and type and neotype strains were deposited in four recognized culture collection.

However, attempts to compare and delineate Streptomyces species were considered to be beyond the scope of the project. Despite the limitations of the ISP, especially its narrow data base, the results were used by several workers to construct identification schemes (Arai \& Mikami, 1969; Nonomura, 1974). Some of which involved-computer analysis (Gyllenberg. 1970; Gyllenberg et al., 1975).

Sporulation medium (Horvath, 1968), Sporulation medium (Hopwood and Sermonti, 1962), Antibiotic production medium (Leach et al., 1951), Muller Hinton medium, Nutrient agar, Glycerol asparagine agar (Koyama et al., 1976), Pigment formation medium (Waksman, 1967).

Detection of cell wall components 
included Determination of diamino pimelic acid (DAP), Determination of cell wall sugars, Determination of mycolic acid was done according to (Kutzner, 1975).

Variability testing in Streptomyces strains was done according to (Horvath, 1968)

Determination of antibiotic sensitivity was done according to (Okami, et al., 1960).

\section{Results and discussion}

Numerical taxonomy is of a value for both classification and identification. The phena defined are polythetic, so no single character is either indispensable or sufficient to entitle an organism to a group membership.

The principles of numerical taxonomy are, therefore, in sharp contrast to the traditional approaches to streptomycetes taxonomy which have usually involved recognition of taxa on the basis of a few subjectively chosen charters.

In this study, 55 characters possessed by the Streptomyces isolates were studied and taken in concern with the same weight. These were useful to minimize error test during grouping and clustering the local isolates.

Results obtained are shown in table (1) and referred to by 1 and 0 according to the presence or absence of the criteria respectively.
Determination of biological activity was done according to (Rudd and Hopwood, 1979).

Biochemical tests included Test for lysozyme resistance, Sugar utilization test, Organic acid formation, Urea utilization, Blood hemolysis, Test for catalase reaction, was done according to (Kutzner, 1975).

Criteria in table (1) were morphology that included spore type (Rectiflixibilis RF, Retinaculiapetri RA, and spira), spore chain ornamentation (Smooth, warty, hairy, and spiny), color of aerial mycelia (grey or white), pigmentation of substrate mycelia (red, orange, pink, yellow, creamy, and brown), antibiotic sensitivity for 14 type including two used as anti cancer drug, biological activity against Gram positive, Gram negative, eukaryotic microorganisms, growth at different incubation temperatures $\left(10-45^{\circ} \mathrm{C}\right)$, growth on different carbon sources, resistance to lysozyme, blood hemolysis, organic acid formation, catalase reaction, urea utilization, and growth on Czapeck's medium.

Before performing statistical test on the results, these results should be interpreted carefully, as similarities between strains can be distorted by test and sampling 
error, low test reproducibility, and the choice of statistical analysis method. This leads to construction of phena artifacts. However, quality of the test data can be assessed by estimating test error, determining the content of relationship of clusters defined by different statistical procedures, and comparing the results of numerical classification with those based on chemical and genetical criteria. For this reason, in the present study, the taxonomic grouping was markedly affected by test error that was low at $0.36 \%$.

Depending on the previous numerical data, and test error statistics, relationship among the local isolates of Streptomyces was re sampled as a dendogram illustrating grouping and distance among these isolates as shown in figure (1). 
Table (1): Overall criteria studied in Streptomysec isolates under study. 1 referrers to the presence of the criteria and 0 absences of these criteria.

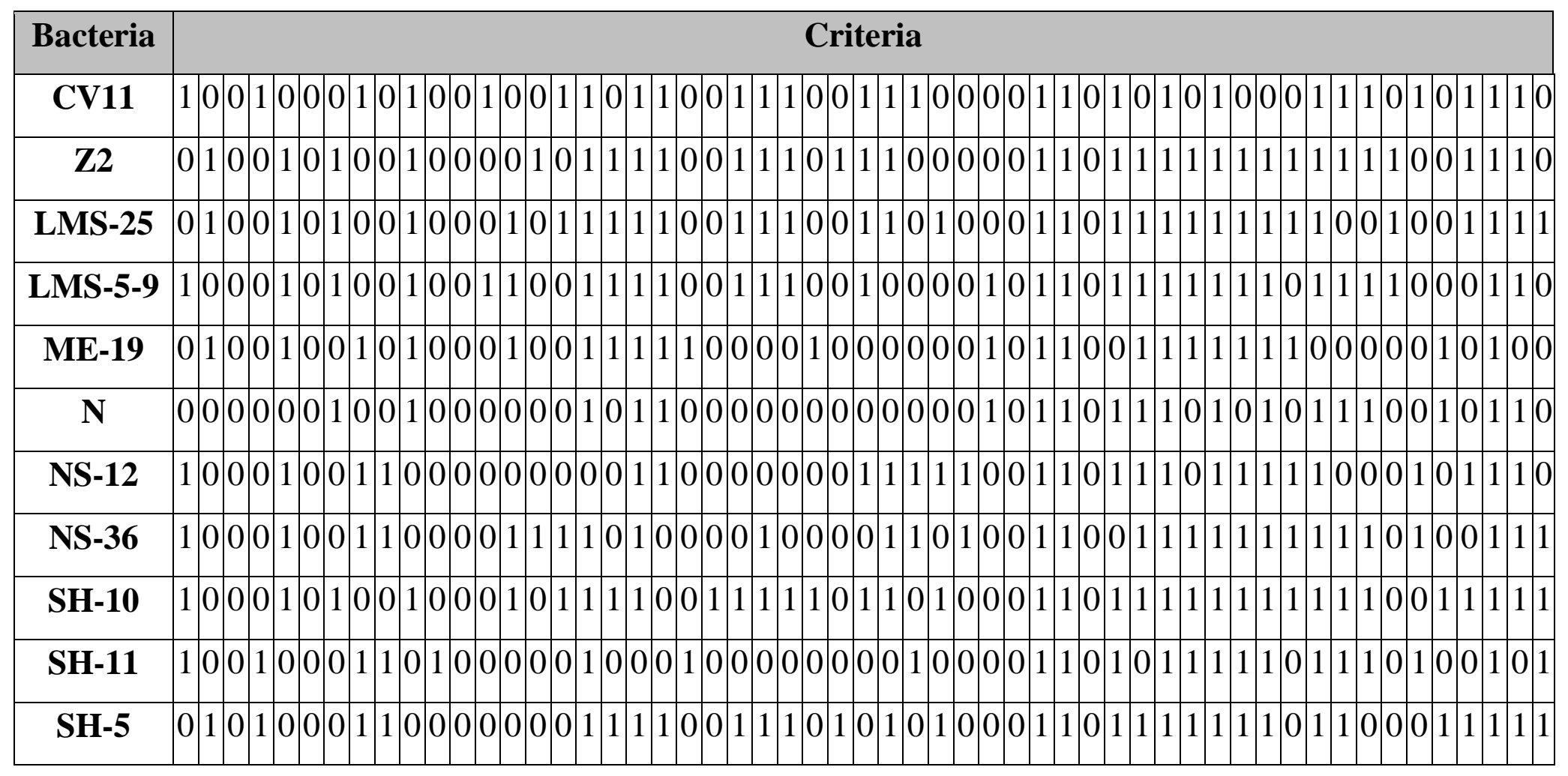




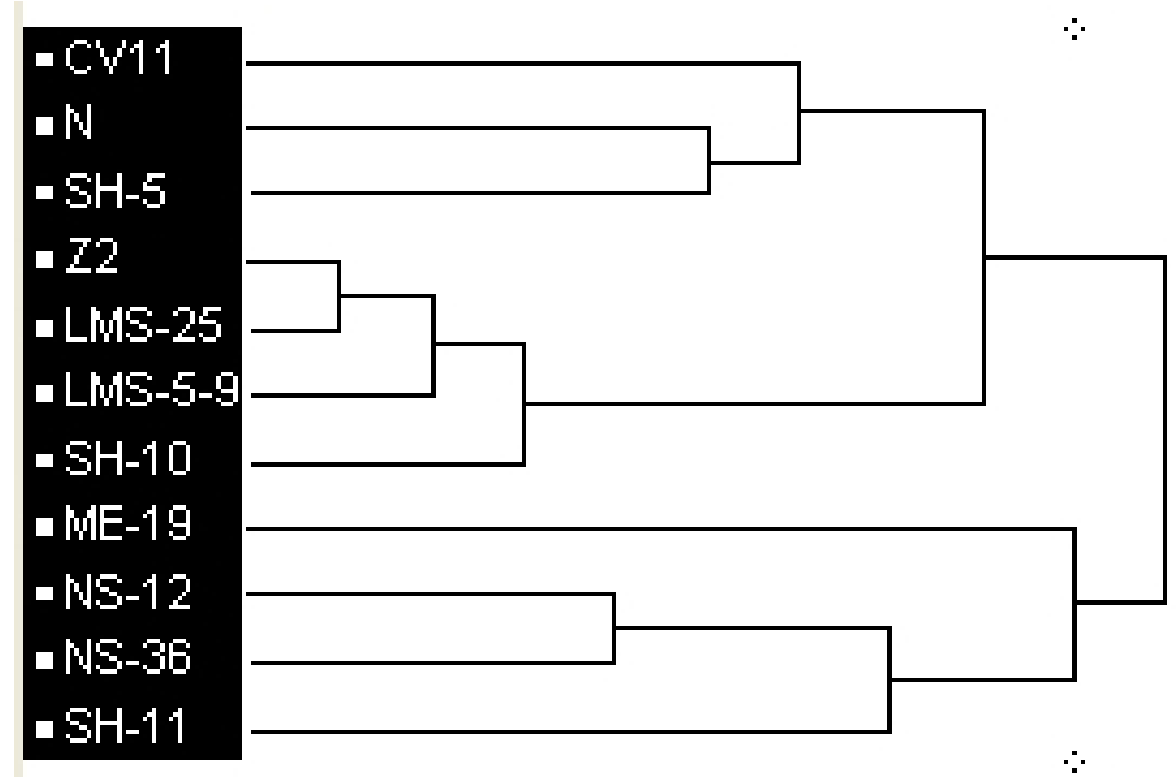

The figure shows presence of two major classes, the upper one includes two branched clusters whereas the lower one branched cluster connected to two taxa. Distance among taxa been tested is shown in table (2).

Table (2): Distance calculated among taxa been classified. Distance values are arranged according to taxa showing the lowest divergence.

\begin{tabular}{|c|c|c|c|}
\hline Number of clusters & Distance & Leader & Joiner \\
\hline 10 & 0.4238195556 & Z2 & LMS-25 \\
\hline 9 & 0.50683816 & Z2 & LMS-5-9 \\
\hline 8 & 0.57350565 & Z2 & SH-10 \\
\hline 7 & 0.580315322 & NS-12 & NS-36 \\
\hline 6 & 0.629042482 & N & SH-5 \\
\hline 5 & 0.663599093 & CV11 & N \\
\hline 4 & 0.727506614 & NS-12 & SH-11 \\
\hline 3 & 0.743809803 & CV11 & Z2 \\
\hline 2 & 0.79041254 & ME-19 & NS-12 \\
\hline 1 & 0.924385406 & CV11 & ME-19 \\
\hline
\end{tabular}


It might be concluded that there are two ancestors for taxa classified these are bacterial strains designated CV11, and ME 19 since they gave the longest distance between and other taxa were diverged from them.

However, depending on standards of ISP classification published by Williams et al., 1981, local isolates of Streptomyces can be classified as in table (3).
Comparing classified strains according to ISP with the dendogram chart obtained previously we can find they agree with each other in matter of relationship among taxa been studied. However, the enigma was with those strains that were not classified meaning that they need more investigation. 
Table (3): Classification of Streptomyces isolates. $\mathrm{RA}=$ retinaculiapetri, $\mathrm{RF}=$ rectiflixibilis, $\mathrm{Sm}=\mathrm{smooth}, ?=$ not classified (Williams et al., 1981)

\begin{tabular}{|c|c|c|c|c|c|c|}
\hline No. & Strain & $\begin{array}{l}\text { Spore } \\
\text { color }\end{array}$ & Spore chain morphology & Melanin production & $\begin{array}{l}\text { Spore surface } \\
\text { ornamentation }\end{array}$ & $\begin{array}{c}\text { ISP Streptomyces } \\
\text { group }\end{array}$ \\
\hline 1. & $\mathrm{Z} 2$ & Grey & RA & - & Hairy & S. rochei \\
\hline 2. & $\mathrm{SH}-5$ & White & RA & - & $\mathrm{Sm}$ & S. diataticus \\
\hline 3. & SH -10 & Grey & $\mathrm{RF}$ & + & Hairy & S. chromofucud \\
\hline 4. & SH -11 & White & $\mathrm{RF}$ & - & $\mathrm{Sm}$ & S. atroolivaceus \\
\hline 5. & $\mathrm{~N}$ & Grey & RA & + & Hairy & $?$ \\
\hline 6. & $\mathrm{NS}-12$ & White & $\mathrm{RF}$ & - & Hairy & S. chromofucud \\
\hline 7. & $\mathrm{NS}-36$ & White & $\mathrm{RF}$ & + & Hairy & S. chromofucud \\
\hline 8. & $\mathrm{ME}-19$ & White & RA & + & Hairy & $?$ \\
\hline 9. & LMS - 25 & Grey & RA & + & Hairy & S. rochei \\
\hline 10. & LMS - 5-9 & Grey & $\mathrm{RF}$ & + & Hairy & S. rochei \\
\hline 11. & CV -11 & White & RF & - & $\mathrm{Sm}$ & S. atroolivaceus \\
\hline
\end{tabular}




\section{References}

1. Arai, T. and Mikami, Y. (1969). Identifaction key for antibiotic producing Streptomyces. Antifungal antibiotic producers. Ann. Rep. Ins. Food. Microbiol. Chiba University, 22: 59.

2. Becker, B., Lechevalier, M. P., and Lechevalier, H. (1965). Chemical composition of cell wall preparations from strains of various form - genera of aerobic actinomycetes. App. Microbiol. 13: 236.

3. Benedict, R. G., Pridham, T. G., Lindenfelser, L. A., Hall, H. H., and Jackson, R. W., (1955). Further studies in the evaluation of carbohydrate utilization tests as aids in differentiation of species of Streptomyces. App. Microbiol. 3: 1.

4. Gause, G. F., Preobrazhenskaya, T. P., Kudrina, E. S., Blinov, N. O. Ryabova, I. D., and Stevinkova, M. A., (1957). Problems in the classification of antagositic actinomycets. Moscow, State Pub., House Medical Literature, Medzig.

5. Gottlieb, D. and Shirling, E. B. (1967). Cooperative description of type cultures of Streptomyces. Int. J. Sys. Bacteriol. 17: 315.

6. Gyllenberg, H. G. (1970). Factor analytical evaluation of patterns of correlated characteristics in streptomycetes. In: the Actinomycetales. Pp: 101.

7. Gyllenberg, H. G., Niemela, T. K., and Niemi, J. S. (1975). A model for automatic identification of streptomycetes. Postepy higieny I medycyny doswiadczalnej 29: 357.

8. Hopwood, D. A.; and Sermonti, G. (1962). The genetics of Streptomyces coelicolor. Adv. Genet. 11: 273.

9. Hopwood, D.A.; Bibb, M. J.; Chater, K. F.; Kieser, T.; Bruton, C. J.; Kieser, H. M.; Lydiate, D. J.; Smith, C. P.; and Ward, J. M. (1985). Genetic manipulation of Streptomyces. A Laboratory Manual. John Innes Inc, Norwich, England.

10. Horvath, J. (1968). Fundamental genetics of Streptomyces. Akademia Kiado, Budapest.

11. Hutter, R. (1967). Sytematika der streptomyceten. Basel: S. Karger.

12. Komagata, K. (1986). JMC catalogue of strains. $\left(3^{\text {rd }}\right)$ edition, Japan.

13. Koyama, Y.; Kato, F.; and Yazawa, Y. (1976). Effect of light on pigmentation of bacteria in actinomycetales. In: Actinomycetes the boundary microorganisms, (Arai, T. ed), Toppan Co. Ltd., pp: 65. 
14. Kutzner, H. J. (1975). The family streptomycetaceae. In: The Actinomycetes. Brown, J. K., and Fowler, M. L. (eds). Berlin, pp: 2055. 15. Leach, B. E.; DeVries, W. H.; Nelson, H. A.; Jackson, W. G.; and Evans, J. S. (1951). The isolation and characterization of Neomycin. J. Amer.

Chem. Soc. 73: 2797.

16. Nonomura, H. (1974). Keys for the identification and classification of 458 species of streptomycetes included in the ISP. J. Ferm. Tech. 52: 78.

17. Okami, Y. (1952). Utilization of nitrogen compounds by streptomycetaceae and its application to classification. Jap. J. Med. Sci. Biol. 5: 265.

18. Okami, Y.; Hashimoto, T.; and Suzuki, M. (1960). Sensitivity of some actinomycetes to antibiotics as a guide to identification. J. Antibiot. 13: 223.

19. Okanishi, K.; Suzuki, K.; and Umezawa, H. (1974). Formation and reversion of Streptomyces protoplast: cultural conditions and morphological study. J. Gen. Microbiol. 80: 389.

20. Pridham, T. G. (1976). Contemporary species concepts in actinomycetales. In: Actinomycets the boundary Microorganisms. Ari T. (ed) Tokyo, pp:163.

21. Pridham, T. G. and Tenser, H. D. (1974). Streptomyces. Waksman and
Hinrici (1943), 339, In: Bergey's Manual of Determinative Bacteriology, 8th ed., pp: 748.

22. Pridham, T. G., Hesseltin, C. W., and Benedict, R. G. (1958). A guide for the classification of streptomycetes according to selected groups. Placement of strains in morphological sections. App. Microbiol. 6: 52.

23. Pridham, T. G., Lyons, A. J., and Seckinger, H. L., (1965). Comparison of some dried holotype and neotype specimens with their living counterparts. Int. Bull. Bacteriol. Nom. Tax. 15:91.

24. Rudd, A. M.; and Hopwood, D. A. (1979). Genetics of actinorhodin biosynthesis by Streptomyces coelicolor A3 (2). J. Gen. Microbiol. 114: 35 .

25. Shinobu, R. (1958). Physiological and cultural study for the identification of soil actinomycetes species. Memories of the Osaka University of the Libral Arts and Eduaction. 7: 1.

26. Shirling, E. B., and Gottlieb, D. (1966). Methods for characterization of Streptomyces species. Int. J. Sys. Bacteriol. 16: 313.

27. Shirling, E. B.; and Gottlieb, D. (1968). Comparative description of type cultures of Streptomyces III. Additional species descriptions from 
first and second studies. Int. J. Syst. Bacteriol. 18: 279.

28. Stackebrandt, E, and Woese, C. R. (1981). The evaluation of prokaryotes.

Symposia of the Society for General

Microbiology.

29. Trejo, W. H. (1970). An evaluation of some concepts and criteria used in the speciation of streptomycetes. Transactions of the New York Academy of Science. 32: 989.

30. Trenser, H. D., and Danga, F. (1958). Hydrogen sulfide production by Streptomyces as criteria for species differentiation. J. Bacteriol. 76: 239.

31. Waksman, S. A. (1957). Species concept among the actinomycetes with special reference to the genus Streptomyces. Bacteriol. Rev. 21:1.
32. Waksman, S. A. (1961). The Actinomycetes. Vol. II, Classification, Identification, and Description of genera and species. Baltimore: Williams and Wilkins.

33. Waksman, S. A. (1967). The actinomycetes. A summary of current knowledge. Ronald Press Co., New York.

34. Waksman, S. A., and Hinrici, A. T. (1943). The nomenclature and classification of the actinomycetes. J. Bacteriol. 46, 337.

35. Williams, S. T., Goodfellow, M., Alderson, G., Willington, E. M. H., Sneath, P. H. A., and Sackin, M. J., (1981). Numerical classification of Streptomyces and related genera. J. Gen. Microbiol. 129: 1743. 